\title{
Cauza justificativă a consimțământului cu privire la transmiterea unor boli infecto- contagioase $^{1}$
}

\section{Av. drd. Dorel Herinean}

\section{Facultatea de Drept, Universitatea din București}

Rezumat: In contextul situației pandemice cauzate de COVID-19, preocuparea majoră în spațiul public este împiedicarea transmiterii bolii și evitarea răspândirii infectării în rândul populației. Alături de celelalte mecanisme angrenate de autorităţile statului în lupta împotriva pandemiei, dreptul penal a fost implicat prin modificarea infracțiunii de zădărnicire a combaterii bolilor, cea care protejează valoarea socială a sănătății publice. Articolul iși propune să studieze condițiile, incidența și efectele cauzei justificative a consimțământului persoanei vătămate în privința răspunderii penale pentru această infracțiune.

Cuvinte-cheie: cauza justificativă, consimțământul persoanei vătămate, zădărnicirea combaterii bolilor, boală infectocontagioasă

The justification cause of the consent expressed in relation to the transmission of an infectious disease

\begin{abstract}
In the context of the pandemic situation caused by COVID-19, the major concern in the public space is to prevent the transmission of the disease and to avoid the spread of the infection among the population. Along with the other mechanisms involved by the state authorities in the fight against the pandemic, criminal law has been involved in amending the crime of thwarting the fight against disease, which protects the social value of public health. The article aims to study the conditions, incidence and effects of the cause justifying the consent of the injured person regarding the criminal liability for this crime.
\end{abstract}

Keywords: justification cause, consent of the victim, preventing the fighting of diseases, transmission of infectious disease

\footnotetext{
${ }^{1}$ Prezentul material pornește de la prelegerea cu tema „Considerente privind cauzele justificative pe perioada stării de urgență”, susținută pe 31 martie 2020 la Conferința online „Urgența în Drept”, organizată de Facultatea de Drept, Universitatea din București. Înregistrarea video este disponibilă pe Canalul Youtube al Facultății de Drept.
} 
Situația curentă cauzată de pandemia COVID-19 creează în practică situații noi, care nu au fost analizate în trecut de doctrină și jurisprudență. Totodată, comportamentul oamenilor este într-o oarecare măsură imprevizibil, dată fiind confruntarea cu situații care nu au mai apărut în anterior. Una dintre caracteristicile bolii infecto-contagioase cu care ne confruntăm la acest moment, privită din perspectiva unui jurist, nicidecum a unui medic de specialitate, respectiv posibilitatea transmiterii acesteia de către persoane asimptomatice, conduce la comportamente umane imprevizibile și cauzatoare de riscuri pentru cei din jur.

Mai mult decât atât, încurajați de lipsa simptomelor sau a oricăror forme de manifestare a bolii, mulţi oameni doresc să își asume riscul îmbolnăvirii pentru a putea să își trăiască viața într-un mod normal și cât mai plăcut în această perioadă. Scopul prezentului articol este studierea consecințelor asumării unui asemenea risc, din perspectivă penală, respectiv în ce măsură exprimarea consimțământului privind intrarea în contact cu o persoană posibil infectată va putea elimina răspunderea penală a acesteia, în cazul în care se produce îmbolnăvirea celeilalte persoane.

\section{Conditii generale de aplicare}

Cauza justificativă a consimțământului este reglementată la art. 22 C. pen.: (1) Este justificată fapta prevăzută de legea penală săvârșită cu consimțământul persoanei vătămate, dacă aceasta putea să dispună în mod legal de valoarea socială lezată sau pusă în pericol. (2) Consimțământul persoanei vătămate nu produce efecte în cazul infracțiunilor contra vieții, precum și atunci când legea exclude efectul justificativ al acestuia.

După cum se poate observa, limitele de incidență ale acestei cauze justificative sunt restrânse, astfel încât a revenit doctrinei rolul de a dezvolta niște criterii pe baza cărora să se stabilească aplicabilitatea acesteia.

\subsection{Valoarea socială disponibilă}

Cea mai importantă condiție referitoare la posibilitatea existenței consimțământului este ca valoarea socială ocrotită la care se renunță să fie una de care titularul său să poată dispune. În primul rând, nu este posibilă oferirea consimțământului pentru comiterea unor infracțiuni care se îndreaptă contra vieții, indiferent de localizarea acestora în Codul penal, categoria 
nefiind restrânsă doar la cele din Capitolul I al Titlului I din Partea specială². Astfel, consimțământul este exclus pentru infracțiunile care au produs ori prin care s-a urmărit moartea unor persoane, indiferent de forma de vinovăție cu care sunt comise.

Suplimentar faţă de situația exceptată expres de legiuitor, trebuie verificate în concret valorile sociale implicate, dacă acesta pot fi disponibile titularului. Fără a analiza in extenso această condiţie, arătăm că două valori sociale interesează prezenta analiză, respectiv sănătatea (integritatea corporală) unei persoane și valoarea socială ocrotită de norma de incriminare de la art. 352 C. pen., aceasta din urmă fiind discutată infra, în cadrul prezentării infracțiunii premisă.

Raportat la caracterul disponibil al sănătăţii și integrităţii fizice a unei persoane, se arată în doctrină că acesta există în măsura în care nu se ajunge la o pierdere totală și ireversibilă a acestei valori sociale ${ }^{3}$. Totuși, tot în doctrină se arată că acordul, chiar cu privire la o valoare socială disponibilă, nu va mai fi valabil dacă este dat cu scopul de a aduce atingere unei alte valori sociale indisponibile, fiind dat exemplul producerii unei vătămări în scopul sustragerii de la serviciul militar pe timp de război ${ }^{4}$.

În același sens, alți autori arată că drepturile individuale precum sănătatea și integritatea corporală sunt drepturi disponibile în principiu, dacă nu au ca efect sacrificarea totală a acestuia sau nu sunt contrare ordinii publice ori bunelor moravuri ${ }^{5}$. Aceiași autori arată că, de principiu, consimțământul poate viza comiterea faptelor prevăzute la art. 193 C. pen., dar cu privire la faptele de la art. 194 alin. (1) C. pen., se arată că acestea au un caracter ireversibil natural, sens în care nu va putea opera, de regulă, această cauză justificativă ${ }^{6}$.

Suplimentar, doctrina a elaborat următoarele condiții de existență ale consimțământului ca o cauză justificativă: valabil exprimat, actual, determinat și exprimat de titularul valorii sociale ocrotite ${ }^{7}$.

\subsection{Valabilitatea consimțământului}

Caracterul valabil exprimat al consimţământului presupune că acesta trebuie să fie acordat de o persoană care înțelege semnificaţia consimţământului și care îl oferă în cunoștinţă

\footnotetext{
${ }^{2}$ L.-V. Lefterache, Drept penal, Partea generală. Curs pentru studenții anului II, Ediția a II-a, editura Hamangiu, București, 2018, p. 207.

${ }^{3}$ Ibidem.

${ }^{4}$ C-tin. Mitrache, C. Mitrache, Drept penal român, Ediția a III-a, editura Universul Juridic, București, 2019, p. 194.

${ }^{5}$ F. Streteanu, D. Nițu, Drept penal. Partea generală, Volumul 1, editura Universul Juridic, București, 2014, p. 401.

${ }^{6}$ Idem, p. 402.

${ }^{7}$ Idem, p. 397 și urm.
} 
de cauză, nefiind însă condiționat de existența capacității de exercițiu, conform dreptului civil ${ }^{8}$. Astfel, consimțământul va putea fi oferit doar de persoanele care înțeleg riscul de a fi îmbolnăvite (fără a fi necesar a cunoaște exact patologia bolii). În contextul actual, de notorietate a efectelor posibile, credem că o astfel de înțelegere a riscului ar putea fi subînţeleasă.

Raportat la situația copiilor sau a vârstnicilor aflați în stare gravă de boală (care le afectează inclusiv discernământul) și care se află în întreținerea unor persoane posibil infectate sau chiar infectate, eventuala transmitere a bolii nu va putea fi analizată din perspectiva consimțământului, acesta neputând fi exprimat în mod valabil. Fără a intra în detalii, în aceste situații ar putea fi incidente alte cauze justificative, precum starea de necesitate ori îndeplinirea unei obligații.

Totodată, se arată în doctrină că inclusiv consimțământul tacit va putea produce efecte, atâta timp cât comportamentul titularului dreptului este univoc ${ }^{9}$. Astfel, o persoană care continuă, de bună voie, să conviețuiască cu cineva care este infectat sau este posibil să fie infectat, dacă a fost informată corespunzător asupra acestei posibilități, își va fi dat consimțământul pentru o eventuală infectare.

\subsection{Actualitatea consimțământului}

A doua condiție, actualitatea consimțământului, presupune ca acesta să fie exprimat anterior sau concomitent săvârșirii infracțiunii ${ }^{10}$, neputând fi oferit în mod valabil ulterior ${ }^{11}$. În plus, se arată că există și un caracter revocabil al consimțământului, acesta putând fi retras în orice moment ${ }^{12}$. Caracterul revocabil este interesant de analizat în cazul unei infectări cu o boală infecto-contagioasă, având în vedere că riscul infecției se produce din primul moment în care s-a luat contactul cu persoana respectivă. Dacă, să luam un exemplu, persoana acceptă să conviețuiască o săptămână cu persoana infectată, iar ulterior își retrage consimțământul, pentru a verifica existența condiţiei actualităţii consimţământului ar trebui identificat momentul infectării, dacă aceasta a avut loc în perioada consimțită sau nu. În mod evident, o situație de acest gen ar ridica reale probleme raportat la probele pe care ar putea fi fundamentată oricare dintre soluţii.

\footnotetext{
${ }^{8}$ F. Streteanu, D. Nițu, op. cit., p. 398-399.

${ }^{9}$ Idem, p. 399.

${ }^{10}$ Idem, p. 400.

${ }^{11}$ C-tin. Mitrache, C. Mitrache, op. cit., p. 195.

${ }^{12}$ F. Streteanu, D. Nițu, op. cit., p. 400.
} 


\subsection{Caracterul determinat}

Următoarea condiție, caracterul determinat al consimțământului, presupune ca acțiunile consimțite să poată fi determinate anterior comiterii faptei ${ }^{13}$. Deși putem cădea în capcana de a considera că această condiţie ar face inutilă orice discuţie ulterioară, atragem atenția asupra faptului că acest caracter vizează acțiunile, iar nu urmările produse de faptă. Astfel, atâta timp cât acțiunile autorului faptei prevăzute de legea penală sunt determinate, nu este necesar ca urmările să fie și ele determinate, această condiție ținând mai degrabă de cerința de a fí valabil exprimat, de starea de conștientă și asumare care trebuie să caracterizeze, oricum, consimţământul.

\subsection{Proveniența de la titularul valorii sociale}

În fine, ultima condiție este proveniența consimțământului de la titularul valorii sociale ocrotite, pentru care este necesar a fi indicat subiectul pasiv al infracțiunii ${ }^{14}$. Se arată în doctrină că, în principiu, atunci când se aduce atingere atât unui interes individual, cât și unui interes colectiv, vom analiza care este obiectul juridic principal, iar în cazurile în care acesta este un interes colectiv, consimțământul nu va putea produce efecte ${ }^{15}$. Autorii mai precizează că soluția este diferită atunci când infracțiunile pluri-ofensive reprezintă forme agravate ale unor infracțiuni contra persoanei care ar putea fi consimțite, situații în care consimțământul ar putea opera, dând ca exemplu ultrajul ${ }^{16}$.

În opinia noastră, care urmează a fi argumentată infra, considerăm că și în cazul primei categorii de infracțiuni enunțate, când discutăm de un obiect juridic principal și un obiect juridic secundar protejate de aceeași normă, consimțământul va putea produce efecte, dar doar în mod limitat.

\section{Prezentarea infractiunii premisă}

Infracțiunea cu privire la care vom analiza consimțământul este infracțiunea-vedetă a momentului, respectiv Zădărnicirea combaterii bolilor, prevăzută și sancționată la art. 352 C. pen. ${ }^{17}$.

\footnotetext{
13 Idem, p. 403.

${ }^{14}$ Ibidem.

${ }^{15}$ Ibidem.

${ }^{16}$ Ibidem.

${ }^{17}$ Art. 352 C. pen. Zădărnicirea combaterii bolilor
} 
Fără a ne propune la acest moment o analiză extinsă a acestei norme de incriminare, ne vom limita doar la câteva precizări necesare prezentării care va urma ${ }^{18}$. Obiectul juridic principal al acestei infracțiuni este sănătatea publică, astfel cum putem deduce din titlul capitolului în care este situată. Este evident faptul că acest obiect juridic este unul care protejează un interes colectiv și care se subsumează interesului general al statului, astfel încât nu există un titular singular al acestuia.

Din aceste considerente și ținând cont de condițiile de aplicare ale consimțământului prezentate supra, această cauză justificativă nu va putea fi incidentă cu privire la infracțiunea prevăzută la art. 352 C. pen. în ansamblul său, obiectul juridic principal, sănătatea publică, nefiind o valoare socială disponibilă și astfel lipsind cea mai importantă condiţie.

Totuși, analizând multiplele modalități de comitere incluse în norma de incriminare, survine întrebarea dacă nu cumva vom putea analiza incidența acestei cauze justificative raportat la obiectul juridic secundar al unora dintre aceste norme: sănătatea și integritatea fizică

(1) Nerespectarea măsurilor de carantină sau de spitalizare dispuse pentru prevenirea sau combaterea bolilor infectocontagioase se pedepsește cu închisoare de la 6 luni la 3 ani sau cu amendă.

(2) Nerespectarea măsurilor privitoare la prevenirea sau combaterea bolilor infect contagioase, dacă fapta a avut ca urmare răspândirea unei asemenea boli, se pedepsește cu închisoare de la unu la 5 ani.

(3) Transmiterea, prin orice mijloace, a unei boli infectocontagioase de către o persoană care știe că suferă de această boală se pedepsește cu închisoare de la 2 la 7 ani și interzicerea exercitării unor drepturi.

(4) Dacă fapta prevăzută în alin. (2) este săvârșită din culpă, pedeapsa este închisoarea de la 6 luni la 3 ani sau amenda.

(5) Dacă prin faptele prevăzute în alin. (1) și (2) s-a produs vătămarea corporală a uneia sau mai multor persoane, pedeapsa este închisoarea de la 2 la 7 ani și interzicerea exercitării unor drepturi, iar dacă s-a produs moartea uneia sau mai multor persoane, pedeapsa este închisoarea de la 5 la 12 ani și interzicerea exercitării unor drepturi.

(6) Dacă prin fapta prevăzută în alin. (3) s-a produs vătămarea corporală a uneia sau mai multor persoane, pedeapsa este închisoarea de la 3 la 10 ani și interzicerea exercitării unor drepturi, iar dacă s-a produs moartea uneia sau mai multor persoane, pedeapsa este închisoarea de la 7 la 15 ani și interzicerea exercitării unor drepturi.

(7) Dacă prin fapta prevăzută în alin. (4) s-a produs vătămarea corporală a uneia sau mai multor persoane, pedeapsa este închisoarea de la unu la 5 ani și interzicerea exercitării unor drepturi, iar dacă s-a produs moartea uneia sau mai multor persoane, pedeapsa este închisoarea de la 2 la 7 ani și interzicerea exercitării unor drepturi.

(8) Tentativa la infracțiunea prevăzută la alin. (3) se pedepsește.

(9) Prin carantină se înțelege restricția activităților și separarea de alte persoane, în spatii special amenajate, a persoanelor bolnave sau care sunt suspecte de a fi bolnave, intr-o manieră care să prevină posibila răspândire a infecției sau contaminării.

${ }^{18}$ Pentru analize extensive ale acestei infracțiuni, a se vedea G.-A. Lazăr, Modificările propuse pentru modificarea Codului Penal în vederea combaterii răspândirii coronavirusului, publicat în data de 20.03.2020 în secțiunea Forum juridic al Analelor Universității din București, disponibil pe https://drept.unibuc.ro/Forum-juridic-s938ro.htm; G.-A. Lazăr, O necesară precizare în raport de forma de vinovăție cu care sunt săvârșite formele agravate ale infracțiunii de zădărnicire a combaterii bolilor, publicat în data de 02.04.2020 în secțiunea Forum juridic al Analelor Universității din București, disponibil pe https://drept.unibuc.ro/Forum-juridic-s938-ro.htm; G. Zlati, D.V. Leordean, Infracțiunea privind zădărnicirea combaterii bolilor (art. 352 Cod penal). Despre înțelegerea textului de incriminare şi posibilitatea efectuării unei expertize genetice, publicat în 17.03.2020, disponibil pe https://www.penalmente.eu/; R. Slăvoiu, Recenta propunere de modificare a dispozițiilor art. 352 Cod penal. UPDATE: S-a modificat pedeapsa pentru fuga din carantină: Stați acasă!, disponibil pe https://www.juridice.ro/; G.-C. Ioan, G. Zlati, Pandemia covid-19 şi răspunderea penală (i): calificarea juridică şi constituționalitatea O.U.G. nr. 28/2020. Raportul cu răspunderea contravențională, publicat în 03.04.2020, disponibil pe https://www.penalmente.eu/, toate consultate în data de 05.04.2020. 
a unei sau a unor persoane determinate.

Forma infracțională prevăzută la alin. (1) este o infracțiune de pericol abstract ${ }^{19}$, astfel încât nu vom putea vorbi de un subiect pasiv secundar al acestei infracțiuni. Astfel cum s-a arătat în doctrină ${ }^{20}$, dacă urmare a nerespectării măsurilor de carantină sau spitalizare se va produce rezultatul răspândirii bolilor, va fi incidentă varianta agravată de la art. 352 alin. (2) C. pen., pe care o vom analiza în continuare.

Se observă că varianta agravată este o infracțiune de rezultat, fiind necesară ,răspândirea unei asemenea boli". Răspândirea unei boli presupune îmbolnăvirea unor persoane, iar ținând cont de faptul că textul nu distinge și nu stabilește vreo limită cantitativă a numărului de persoane, infracțiunea va fi incidentă dacă se infectează cel puțin o persoană. Or, în acest caz putem discuta deja de un obiect juridic secundar, sănătatea ori integritatea fizică a unor persoane. Se observă astfel că poate exista un subiect pasiv secundar al acestei infracţiuni, respectiv persoana infectată sau persoanele infectate, dacă acestea sunt mai multe.

Forma prevăzută la art. 352 alin. (3) C. pen. presupune transmiterea, prin orice mijloc, a unei boli infectocontagioase. La fel ca în cazul formei de la alin. (2), transmiterea presupune infectarea a (cel puțin) unei persoane, cu consecința existenței unui obiect juridic secundar și a unei/unor persoane care să aibă calitatea de subiect pasiv secundar.

Aceleași concluzii referitoare la existența unui obiect juridic secundar și a unui subiect pasiv sunt valabile și în cazul formelor agravate de la alin. (4)-(7). Prin urmare, premisa discuțiilor care vor urma sunt aceste forme infracționale care presupun atingeri aduse sănătăţii unor persoane.

Totodată, mai facem precizarea că formele infracționale prevăzute la alin. (1)-(3) se comit cu intenție, formele de la alin. (4) și (7) sunt infracțiuni care pot fi comise doar din culpă, iar formele agravate de la (5)-(6) pot fi comise doar cu forma de vinovăţie a intenției depăşite, dată fiind formularea specifică infracțiunilor praeterintenționate ${ }^{21}$.

\section{Posibilitatea exprimării consimtământului raportat la urmările produse din culpă}

Deși această problemă putea fi subsumată condițiilor generale de existență ale

\footnotetext{
19 G.-A. Lazăr, Modificările propuse pentru modificarea Codului Penal în vederea combaterii răspândirii coronavirusului, publicat în data de 20.03.2020 în secțiunea Forum juridic al Analelor Universității din București, disponibil pe https://drept.unibuc.ro/Forum-juridic-s938-ro.htm

${ }^{20}$ Idem.

${ }^{21}$ În același sens, G.-A. Lazăr, O necesară precizare în raport de forma de vinovăție cu care sunt săvârșite formele agravate ale infracțiunii de zădărnicire a combaterii bolilor, publicat în data de 02.04 .2020 în secțiunea Forum juridic al Analelor Universității din București, disponibil pe https://drept.unibuc.ro/Forum-juridic-s938-ro.htm.
} 
consimțământului, am considerat oportună prezentarea separată a acesteia, dat fiind caracterul crucial pentru concluziile care urmează a fi trase.

După cum se precizează în doctrină ${ }^{22}$, posibilitatea consimțământului de a produce efecte cu privire la o infracțiune săvârșită din culpă este admisă în general, cu mențiunea că, în aceste situații, consimțământul va viza acțiunea comisă, iar nu rezultatul. Argumentația constă în necesitatea acordării posibilității ca persoanele să iși asume anumite riscuri raportat la anumite activităţi considerate periculoase, dar legale și la care aleg să participe.

De altfel, putem observa, practic, că această concluzie este o pastișă a caracterului determinat al consimțământului, prezentat supra, care trebuie să vizeze acțiunea, iar nu rezultatul.

Pornind astfel de la premisa că se poate oferi consimțământul și în cazul infracțiunilor din culpă, pe lângă cele intenționate, nu vedem niciun argument pentru care ar putea fi excluse de plano de la o astfel de concluzie infracțiunile comise cu intenție depășită. Totuși, majoritatea infracțiunilor cu intenție depăşită reglementate de Codul penal sunt excluse, dat fiind că au ca urmare mai gravă moarte unei persoane și, așa cum am arătat, consimţământul nu poate fi oferit cu privire la infracțiuni contra vieții, indiferent de forma de vinovăție.

Așadar, în consens cu opiniile doctrinare arătate, considerăm că se va putea reține cauza justificativă a consimțământului cu privire la infracțiunile săvârșite cu intenţie depășită sau din culpă atunci când se consimte cu privire la acțiunea comisă, atâta timp cât sunt îndeplinite și celelalte condiții de existență ale acesteia.

\section{Limitele incidentei consimtământului}

Pornind de la toate premisele și argumentele expuse supra, vom prezenta în continuare opinia noastră raportat la modalitatea în care cauza justificativă a consimțământului ar putea fi incidentă cu privire la infracțiunea premisă.

\subsection{Inaplicabilitatea generală a consimţământului}

Așa cum am menționat deja, indiferent de forma, modalitatea și amploarea cu care este exprimat, consimţământul nu va putea produce efectele de cauză justificativă cu privire la infracțiunea prevăzută la art. 352 C. pen., Zădărnicirea combaterii bolilor, având în vedere că valoarea socială ocrotită de această infracțiune este una colectivă, respectiv sănătatea publică,

\footnotetext{
${ }^{22}$ F. Streteanu, D. Niţu, op. cit., p. 405; I. Nedelcu în G. Bodoroncea, V. Cioclei. I. Kuglay, 1. V. Lefterache, T. Manea, I. Nedelcu, F.-M. Vasile, Codul penal. Comentariu pe articole, editura C. H. Beck, București, 2014 , p. 88.
} 
și nu are un caracter disponibil.

Astfel, de fiecare dată când o persoană va comite, cu vinovăție (și fără incidența altor cauze justificative ori de neimputabilitate), verbum regens al uneia dintre modalitățile de incriminare prevăzute la art. 352 alin. (1)-(4) C. pen., acestea vor răspunde pentru comiterea acestei infracțiuni, indiferent de consimțământul persoanei căreia le-a fost transmisă boala infecto-contagioasă. Acest consimțământ ar putea, eventual, produce efect exclusiv cu privire la infracțiunea prevăzută la art. 193 C. pen., infracțiune cu privire la care s-a arătat însă în doctrină $^{23}$ că ar trebui să fie absorbită natural de această normă de incriminare, date fiind formele agravate, opinie la care aderăm.

$\mathrm{Nu}$ în ultimul rând, pe baza celor prezentate deja în cadrul analizei condițiilor, consimțământul nu va putea fi valorificat dacă acesta este dat cu scopul de a aduce atingere unei alte valori sociale indisponibile, cum este în analiza de faţă sănătatea publică. Astfel, dacă o persoană dorește a fi infectată tocmai pentru a putea infecta, mai departe, alte persoane, atunci nu vom putea discuta de valabilitatea consimțământului acesteia.

4.2. Inaplicabilitatea consimțământului atunci când s-a produs moartea unei persoane

Raportat la formele praeterintenționate ori din culpă prin care s-a produs moartea uneia sau mai multor persoane, incluse la art. 352 alin. (5), (6), (7) tezele secunde C. pen., astfel cum am arătat, nu va putea opera consimțământul, dată fiind limitarea impusă de dispozițiile art. 22 alin. (2) C. pen.

4.3. Sfera de aplicabilitate în cazul infracțiunilor având ca urmare vătămarea corporală a unor persoane

Discuția rămâne a fi purtată cu privire la modalitățile infracționale comise cu intenție depăşită, reglementate tot la art. 352 alin. (5), (6), tezele întâi C. pen,, respectiv la forma din culpă prevăzută la art. 352 alin. (7) C. pen., teza întâi, pe care le vom trata împreună în cele ce urmează.

Așa cum am arătat supra, în cazul faptelor comise cu intenţie depăşită sau din culpă, consimțământul trebuie să vizeze acțiunea generatoare de pericol, iar nu rezultatul. Exemple de acțiuni ar putea fi conviețuirea cu persoana infectată sau bănuită a fi infectată, vizitarea sau primirea vizitei unei astfel de persoane, utilizarea în comun a unor bunuri (e.g. mașină) sau obiecte de uz casnic, etc. Amintind și celelalte condiții ale consimţământului, am arătat deja că

\footnotetext{
${ }^{23}$ G.-A. Lazăr, O necesară precizare ..., cit. supra.
} 
trebuie să fie exprimat în mod univoc (chiar și tacit) și să provină de la o persoană care poate să îl ofere conștient și în cunoștință de cauză.

Totuși, nu este exclusă acceptarea consecințelor de către persoana vătămată. Ba mai mult, amintim că în situația analizată este vorba de un rezultat specific infracțiunii de vătămare corporală, cu privire la care am arătat că doctrina este reticentă în a da aplicabilitate consimțământului. Din aceste motive, considerăm că ar fi necesar ca, în vederea unui raționament riguros, consimțământul să vizeze și posibilele rezultate prevăzute de norma de incriminare pentru a fi aplicabil și valabil exprimat în astfel de cauze.

Fără a încerca exprimarea unei opinii medicale în acest sens și bazându-ne inclusiv pe cele analizate în general de doctrină în cazul infracțiunii de vătămare corporală, vom considera că nu va putea fi exprimat un consimțământ valabil, în contextul infectării cu o boală infectocontagioasă (avem aici în vedere în special COVID-19), cu privire la consecințele de la art. 194 alin. (1) lit. a), c), d) acestea nefiind, de regulă, urmări firești ori previzibile ale unei asemenea infectări ${ }^{24}$.

$\mathrm{Cu}$ toate acestea, deși poate părea nefiresc puțin acest exemplu raportat la posibilitatea de prevedere a unor astfel de consecințe, în situația în care consimțământul ar viza posibilitatea producerii unor leziuni traumatice sau afectarea sănătății persoanei, care să necesite, pentru vindecare, mai mult de 90 de zile de ingrijiri medicale, considerăm că acesta ar putea fi considerat valabil, dat fiind (și) faptul că soluția este în consens cu cele exprimate de doctrină, nefiind cauzate pierderi totale sau ireversibile ale sănătății.

În plus, aceeași concluzie considerăm că poate fi trasă și cu privire la consecința prevăzută la art. 194 alin. (1) lit. e) C. pen., punerea în primejdie a vieții, ținând cont de faptul că orice boală poate cauza, statistic, decesul unei persoane, conform ratei sale de mortalitate. Astfel, la momentul asumării infectării cu o boală, există o șansă ca acea boală să provoace moartea persoanei, neputând fi exclus de plano vreodată acest rezultat ${ }^{25}$. Or, în acest context, considerăm că atunci când o persoană își va exprima consimțământul cu privire la infectarea cu o boală, acceptă posibilitatea, cât de mică, a producerii unui rezultat fatal pentru aceasta.

Raportat la această consecință, există unele limite pe care dorim să le subliniem. Mai întâi, dacă persoana care transmite boala dorește sau acceptă posibilitatea ca persoana ce va fi

\footnotetext{
${ }^{24}$ Subliniem aici caracterul speculativ și profan din punct de vedere medical al acestei afirmații, nefiind bazată pe vreun studiu sau fundament medical.

${ }^{25}$ Subliniem, şi aici, caracterul speculativ și profan din punct de vedere medical al acestei afirmații, nefiind bazată pe vreun studiu sau fundament medical.
} 
infectată să moară, va fi incidentă tentativa la infracțiunea de omor, cu intenţie directă sau indirectă, și nu o eventuală vătămare corporală. Doctrina a subliniat în repetate rânduri ${ }^{26}$ că diferența dintre tentativa la omor și vătămarea corporală care a avut ca o consecință punerea în primejdie a vieții persoanei este dată de elementul subiectiv, aceasta din urmă fiind comisă cu intenție depășită, iar prima cu intenție directă ori indirectă. Or, dacă se urmărește sau acceptă producerea morții unei persoane, vom vorbi de o infracțiune contra vieții, exceptată expres de legiuitor la art. 22 alin. (2) C. pen. Apoi, dacă se produce rezultatul și persoana moare, vom vorbi, din nou, de o infracțiune contra vieții, nemaifiind aplicabil consimțământul.

Astfel, în opinia noastră, în situațiile în care persoana și-ar asuma infectarea cu o boală şi ar accepta posibilitatea producerii unor leziuni traumatice sau afectarea sănătății sale, pentru care să aibă nevoie de mai mult de 90 de zile de îngrijiri medicale ori și-ar asuma posibilitatea punerii în primejdie a vieții (fără ca acest rezultat să fie urmărit sau acceptat de autor ori să se producă), consimţământul acesteia ar putea fi avut în vedere ca o cauză justificativă cu privire la sănătatea sa și la integritatea sa corporală.

În această situație, dată fiind forma agravată și infracțiunea complexă prevăzută de legiuitor, revenim la cele arătate supra referitor la necesitatea exprimării consimțământului de către titularul valorii sociale ocrotite, respectiv opinia doctrinară conform căreia atunci când sunt protejate un interes individual și unul colectiv, obiectul juridic principal va da caracterul disponibil sau nu al valorii sociale ocrotite ${ }^{27}$.

Am putea fi tentați să includem infracțiunea de zădărnicirea combaterii bolilor în excepția prezentată de aceiași autori, respectiv infracțiunile care protejează și un interes general, dar care sunt forme agravate ale unor infracțiuni contra unui interes individual ${ }^{28}$, disponibil, însă nu suntem de părere că o astfel de categorisire ar fi riguroasă, nefiind vorba de o astfel de formă agravată a unei eventuale infracțiuni de vătămare corporală ori vătămare corporală din culpă.

Deși suntem de acord cu această opinie ca regulă generală, considerăm că pot exista și alte situații de excepție, în care consimțământul va putea produce efecte în mod limitat. Astfel, în situații precum cea din speță, în care avem o infracțiune complexă în care obiectul juridic principal este un interes colectiv, iar obiectul juridic secundar este un interes individual și totodată disponibil, apreciem că ar trebui să fie dată eficacitate acestui consimțământ în vederea

\footnotetext{
${ }^{26}$ A se vedea, de exemplu, V. Cioclei, Drept penal. Partea Specială I. Infracțiuni contra persoanei și infracțiuni contra patrimoniului, Ediția 4, editura C. H. Beck, București, 2019, p. 73.

${ }^{27}$ F. Streteanu, D. Nițu, op. cit., p. 403.

${ }^{28}$ Idem.
} 
înlăturării formei agravate a infracțiunii, autorul urmând a răspunde doar pentru forma de bază.

Argumentul constă în aceea că, în lipsa formei agravate, autorul ar răspunde pentru un concurs de infracțiuni între infracțiunea în forma de bază și vătămarea corporală (fie ea cu intenție ori din culpă), iar în acest caz, cauza justificativă ar înlătura caracterul infracțional al celei de-a doua, astfel încât ar rămâne incidentă o singură infracțiune. Nu considerăm că există vreo diferență de pericol social, raportându-ne strict la obiectul juridic secundar, sănătatea ori integritatea fizică a unei persoane (întrucât diferența e sancționată oricum prin reținerea infracțiunii de la art. 352 C. pen.), între autorul care cauzează vătămarea corporală prin loviri sau autorul care cauzează vătămarea corporală prin transmiterea unei boli. Din nou, este esențială pentru acest raționament sancționarea pentru infracțiunea în formă de bază, dată fiind atingerea adusă obiectului juridic principal.

Or, deși acest raționament poate fi criticat, așa cum vom arăta, soluția contrară imposibilitatea valorificării parțiale a consimțământului - ni se pare inechitabilă și indiferentă scopului existenței acestei cauze justificative.

Pentru a privi din perspectivă inversă, soluția propusă prin prezenta lucrare ar putea fi criticată chiar de definiția legală a infracțiunii complexe prevăzută la art. 35 alin. (2) C. pen.: „Infracțiunea este complexă când în conținutul său intră, ca element constitutiv sau ca element circumstanțial agravant, o acțiune sau o inacțiune care constituie prin ea însăși o faptă prevăzută de legea penală”. După cum se poate observa, se vorbește despre faptă prevăzută de legea penală, iar nu de infracțiune. Or, se poate susține astfel că cauzele justificative vor fi verificate cu privire la întreaga infracțiune complexă, neputând fi verificate separat cu privire la fiecare dintre faptele prevăzute de legea penală care o compun.

Un alt argument împotriva soluției propuse ar fi caracterul unitar al infracțiunii complexe, astfel cum se arată în doctrină: „Infracțiunea complexă reunește în conținutul ei conținutul altor infracțiuni, care iși pierd autonomia, iar incidența celorlalte instituții de drept penal se apreciază în raport de unitatea legală complexă" ${ }^{29}$ Astfel, pe baza acestui raționament, cauza justificativă ar trebui raportată la întreg, iar nu la fiecare componentă a infracțiunii complexe în parte. Or, analizând cauza justificativă raportat la obiectul juridic principal, aceasta nu ar putea fi incidentă. Un ultim argument contra ar fi opinia doctrinară conform căreia rațiunea creării infracțiunii complexe este de a pune în evidență pericolul sporit al faptelor comise în legătură

\footnotetext{
${ }^{29}$ L. V. Lefterache, op. cit., p. 358.
} 
unele cu altele, față de situația în care ar fi comise separat ${ }^{30}$.

Deși suntem de acord cu opiniile și argumentele care fundamentează soluția contrară, astfel cum au fost prezentate supra, considerăm că, deși nu se distinge, toate acestea vizează mai degrabă infracțiunea complexă ca formă tip (cum este tâlhăria), iar nu infracțiunea complexă ca variantă agravată.

Soluția propusă de noi este contraintuitivă și din perspectiva faptului că majoritatea infracțiunilor complexe, variante agravate, au ca rezultat mai grav moartea victimei, care protejează o valoare socială esenţialmente indisponibilă, motiv pentru care considerăm că la elaborarea criteriilor de aplicare a cauzei justificative a consimțământului nu s-a acordat o atenție sporită acestor ipoteze.

Deși opinia contrară pare a fi cea mai temeinică, de lege lata, din punct de vedere al argumentelor prezentate, considerăm și rămânem la părerea că în privința acestei infracțiuni și a altora din această categorie - infracțiuni complexe ca variantă agravată, atunci când rezultatul mai grav nu este moartea - cauza justificativă a consimțământului persoanei vătămate poate avea efectul eliminării răspunderii pentru forma agravată care sancționează rezultatul produs din culpă, cu consecința răspunderii autorului pentru infracțiunea în forma de bază, îndreptată împotriva interesului colectiv protejat.

4.4. Precizări suplimentare în funcție de numărul subiecților pasivi secundari

Dat fiind faptul că aceste forme agravate sunt infracțiuni complexe omogene, consecințele pot viza atât o singură persoană, cât și mai multe, limitele de pedeapsă fiind aceleași. Soluția legiuitorului, care a stârnit critici în doctrină ${ }^{31}$, conduce la necesitatea distincției între două ipoteze, în funcție de numărul persoanelor față de care s-a produs vătămarea corporală.

Prima situație a fost deja tranșată supra, arătând criteriile în funcție de care va opera, în opinia noastră, consimțământul persoanei vătămate cu privire la această infracțiune, atunci când există o singură astfel de persoană vătămată.

A doua situație, respectiv cazul în care sunt mai multe persoane afectate, dintre care cel puțin una nu și-a exprimat consimțământul cu privire la posibilitatea îmbolnăvirii, va fi incidentă infracțiunea în forma agravată prevăzută, după caz, la art. 352 alin. (5), (6), (7) tezele întâi C. pen. Soluția se impune având în vedere că este suficient pentru incidenţa acestei norme

\footnotetext{
${ }^{30}$ C-tin. Mitrache, C. Mitrache, op. cit., p. 322. Totuși, considerăm că această rațiune prezentată de autorii citați se referă mai degrabă la infracțiunea complexă tip, iar nu la infracțiunea complexă ca formă agravată.

${ }^{31}$ G.-A. Lazăr, Modificările propuse..., cit. supra.
} 
ca vătămarea corporală să fie produsă unei singure persoane. În aceste cazuri, consimțământul celorlalte persoane ar putea fi, eventual, avut în vedere la individualizarea pedepsei.

\section{Concluzii}

Concluzionând cele expuse anterior, arătăm că, în privința infracțiunii prevăzute la art. 352 C. pen., cauza justificativă a consimțământului nu va putea produce efecte cu privire la formele de bază, sancționate la alin. (1)-(3), la formele agravate care au avut ca rezultat moartea victimei ori la formele agravate având ca rezultat vătămarea corporală a unor persoane, dacă cel puțin o persoană nu și-a dat consimţământul.

De lege lata și privind dintr-o perspectivă strictă, aceeași concluzie va fi trasă și cu privire la formele agravate care au avut ca rezultat vătămarea corporală a persoanelor, dat fiind faptul că singurul argument de text care poate fundamenta una dintre soluții este definiția infracțiunii complexe unde, astfel cum am arătat, se menționează că este formată din fapte prevăzute de legea penală, astfel încât caracterul justificat se va analiza raportat la întreaga tipicitate a infracțiunii complexe, neexistând vreun temei legal în baza căruia să putem desprinde cele două infracțiuni componente.

Prin excepție, din considerente de echitate și de aplicabilitate mai extinsă a acestei cauze justificative, cu posibilitatea preluării de lege ferenda, pornind de la opinia exprimată în prezentul articol și luând în considerare caracterul generic al contra-argumentelor doctrinare prezentate, totodată, în cuprinsul prezentului articol, considerăm că această cauză justificativă ar putea fi valabilă cu privire la forma agravată având ca rezultat vătămarea corporală a unei persoane, dacă aceasta a exprimat un consimțământ valabil, în cunoștință de cauză cu privire la acțiunile autorului care pot cauza îmbolnăvirea și cu privire la eventualele consecințe tipice produse, respectiv cele de la art. 194 alin. (1) lit. b) și e) C. pen.

Materialul a fost publicat în revista online a Facultăţii de Drept, $\underline{\text { AUBD-Forum Juridic nr. }}$ $\underline{1 / 2020 .}$ 